Research Article

\title{
Prediction of Plastic Shrinkage Cracking of Self-Compacting Concrete
}

\author{
Parviz Ghoddousi, ${ }^{1}$ Armin Monir Abbasi $\mathbb{D}^{2},{ }^{2}$ Esmail Shahrokhinasab $\left(\mathbb{D},{ }^{3}\right.$ \\ and Mohammad Abedin $\mathbb{D D}^{3}$ \\ ${ }^{1}$ Department of Civil Engineering, Iran University of Science and Technology, Tehran, Iran \\ ${ }^{2}$ Department of Civil Engineering, Payame Noor University, Tehran, Iran \\ ${ }^{3}$ Department of Civil and Environmental Engineering, Florida International University, Miami, FL, USA
}

Correspondence should be addressed to Mohammad Abedin; mabed005@fiu.edu

Received 20 April 2019; Revised 30 June 2019; Accepted 5 September 2019; Published 15 October 2019

Academic Editor: Hayri Baytan Ozmen

Copyright (c) 2019 Parviz Ghoddousi et al. This is an open access article distributed under the Creative Commons Attribution License, which permits unrestricted use, distribution, and reproduction in any medium, provided the original work is properly cited.

\begin{abstract}
Concrete exposed to hot climatic conditions is prone to plastic shrinkage after casting within the first few hours due to the water evaporation and restraining conditions of concrete. This cracking is more commonly observed in concrete elements with a large surface area exposed to drying. In this research, plastic shrinkage of 13 self-compacting concrete samples with different cement paste volumes and various coarse to total aggregate ratios was studied. Test specimens of fresh concrete were subjected to a wind tunnel, which simulated hot dry environmental condition immediately after casting. It can be observed from the test results that the relationship between free plastic shrinkage and the difference between bleeding and evaporation is direct and linear. Finally, a model for plastic shrinkage estimation was suggested by considering the effect of free plastic shrinkage strain, restraining factor, and tensile strain capacity of self-compacting concrete.
\end{abstract}

\section{Introduction}

Self-compacting concrete (SCC) is an innovative flowable type of concrete that does not need any kind of vibration for compaction. This ability comes from special mix design including superplasticizers and viscosity modifier, and mineral fillers. SCC moves using its weight through any tiny spaces without segregation, meanwhile maintains all concrete's durability and characteristics. However, SCC with a large surface to volume ratio is prone to the plastic shrinkage cracking within the first few hours after casting due to the moisture loss, high amount of fine particles, and restraining conditions [1]. Although concrete bleeding may recover some of the water loss, it can develop negative capillary pressure that causes internal compressive strain in the concrete. In the case of the restrained condition, these compressive strains may result in considerable tensile stresses and consequently causes plastic shrinkage. This problem remains a serious concern, particularly in a large surface area, such as ground slabs exposed to hot and/or windy conditions. In these cases, the exposed surface area per unit volume of placed concrete is significantly higher than conventional concrete, and the base surface provides a high degree of restraint [2]. Based on these evidences, it is clear that the estimation of plastic cracking is crucial to enhance the durability of concrete.

In recent years, self-compacting concrete has been studied by several researchers. Loukili and Turcry [3] have studied plastic shrinkage cracking of self-compacting concrete. They found that when the rate of evaporation is equal to the rate of bleeding, negative pore pressure is created. Subsequently, this negative pore pressure that is the main reason for plastic shrinkage in concrete will further develop.

In a study on plastic shrinkage cracking of the concrete, Qi et al. [4] understood that by increasing the amount of difference between the rate of bleeding and evaporation, the amount of negative pore pressure would increase. They also found that as fibers cause the long track of water emission, the bleeding process period of fiber concrete is elongated. 
Wang et al. [5] revealed that by using fiber and fly ash for increasing pore diameters in concrete, it is possible to decrease the tension forces of pore walls and as a result, the plastic shrinkage of concrete will be decreased. Moreover, Erten et al. [6] recently showed that plastic shrinkage cracks could reduce the corrosion resistance of high performance concretes, and fibers can limit the crack width.

Abbasnia et al. [7] and Leung et al. [8] by individual research showed that restraining factors may be calculated by these equations:

$$
\begin{aligned}
\Delta \xi & =\xi_{\mathrm{f}}-\xi_{\mathrm{R}}, \\
R & =\frac{\Delta \xi}{\xi_{\mathrm{f}}} \times 100,
\end{aligned}
$$

where $\xi_{\mathrm{f}}=$ free plastic shrinkage strain, $\xi_{\mathrm{R}}=$ restraint plastic shrinkage strain, and $R=$ restraining factor (\%).

Leemann et al. [9] investigated the impact of different admixtures on the occurrence and extent of plastic shrinkage cracking of SCC. Plastic shrinkage cracking was measured according to ASTM C1579-06 in a climate chamber at a temperature of $30^{\circ} \mathrm{C}$ and relative humidity of $60 \%$. The tests began immediately after casting and parameters, such as settlement, capillary pressure, and mass loss, were recorded. The mechanism for crack prevention was identified from the results.

Boshoff and Combrinck [10] proposed a model to predict the degree of plastic shrinkage cracking. The model was based on the volume of water that evaporates from the concrete between the placing and the initial setting time of the concrete. This model was verified by using a large number of test results. Moreover, many studies conducted on the effect of synthetic microfibers on plastic shrinkage cracking and the durability of concrete structures [11, 12]. The results show that the presence of fibers effectively reduces plastic shrinkage cracking.

Y. Li and J. Li [13] developed a prediction method of early plastic shrinkage of self-compacting concrete based on the capillary tension theory and microstructure pores. Selfcompacting concrete specimens with different strength grades were prepared. The negative pressure of the capillary and plastic shrinkage was determined, and the results showed that predicted values derived from this model were consistent with the measured values.

Altoubat et al. [14] in a study investigated the effect of fly ash (FA) on cracking and relaxation behavior of various SCC mixes. The experimental results revealed that adding FA can improve the cracking resistance and relaxation behavior of SCC mixes. Moreover, curing condition and degree of restraint play an important role in the effectiveness of FA on the cracking and relaxation behavior of SCC mixes. A recent experimental investigation on the feasibility of using SCC in retrofitting damaged structures by Valikhani et al. $[15,16]$ also indicated that adding steel fibers can improve the plastic cracking resistance of SCC mixes. The results showed that SCC mixes with steel fibers could be a practical option for retrofitting deteriorated structures compared to normal concrete.
As discussed, some studies focused on SCC properties and plastic shrinkage; however, none of them evaluated the relationship between bleeding and evaporation in the SCC plastic shrinkage. The purpose of this paper is to investigate the plastic shrinkage properties of self-compacting concrete and develop a new equation for predicting the SCC plastic shrinkage based on the bleeding and evaporation rates.

\section{Experimental Program}

In this paper, a total of thirteen self-compacting concrete samples were studied to investigate the effect of different additives, water/cement ratio, cement paste volume, and the proportion of course aggregate to total aggregate on plastic shrinkage and bleeding behavior of SCC mixtures.

As a result, the effect of each parameter was investigated by keeping the other variables constant in the mixtures.

In the mixtures of 1-4, water/cement and course aggregate/total aggregate ratios were kept constant at the value of 0.4 and cement paste volume was varied from $289 \mathrm{lit} / \mathrm{m}^{3}$ to $359 \mathrm{lit} / \mathrm{m}^{3}$. Mixtures 2, 5, 6, and 7 were used to investigate the effect of water/cement ratio by keeping the other variables constant. Moreover, the effect of coarse aggregate/total aggregate ratio was studied through mixes $8,11,12$, and 13 by keeping the water/cement ratio and cement paste volume constant at the value of 0.04 and $325 \mathrm{lit} / \mathrm{m}^{3}$, respectively. Finally, coarse aggregate/total aggregate ratio was varied from 0.3 to 0.45 in the mixes 2,9 , and 10 .

In general, the desired viscosity of SCC concrete is provided by adding mineral additives or Viscosity Modifier Admixtures (VMA), which increase the consistency of concrete paste. In this research, prepacked VMA admixtures and two different sizes of sand were used to achieve appropriate, workable self-compacting concrete without using an extra mineral additive, such as limestone powder or fly ash. It should be noted that combination of fine and course aggregate improves the workability of self-compacting concrete without affecting strength characteristics.

2.1. Materials. The cement used in all mixes was Type I Portland cement, which corresponds to ASTM Type I with the specific gravity of $3150 \mathrm{~kg} / \mathrm{m}^{3}$ and the coarse aggregate was made of crushed limestone with a nominal maximum size of $19 \mathrm{~mm}$ and a specific gravity of $2550 \mathrm{~kg} / \mathrm{m}^{3}$.

Based on ACI 304.2R-96 [17], for concrete with moving ability, particular attention should be given to those portions passing the finer screen sizes. As a result, it is required to have at least 15 to 30 percent passing No. 50 screen and 5 to 10 percent passing No. 100 screen. Fine aggregates that are deficient in either of these two sizes should be blended with selected fine sands, mineral admixtures, or other materials to produce these desired percentages. In this study, two different sand sizes are used to meet ACI 304.2R-96 requirements. Sand Type I is local natural sand (uncrushed river sand), and Sand Type II is the crushed version of Sand Type I with more percent of passing the finer screen sizes. Blending these two different sand sizes improves the flowability of SCC concrete without using mineral admixtures. 


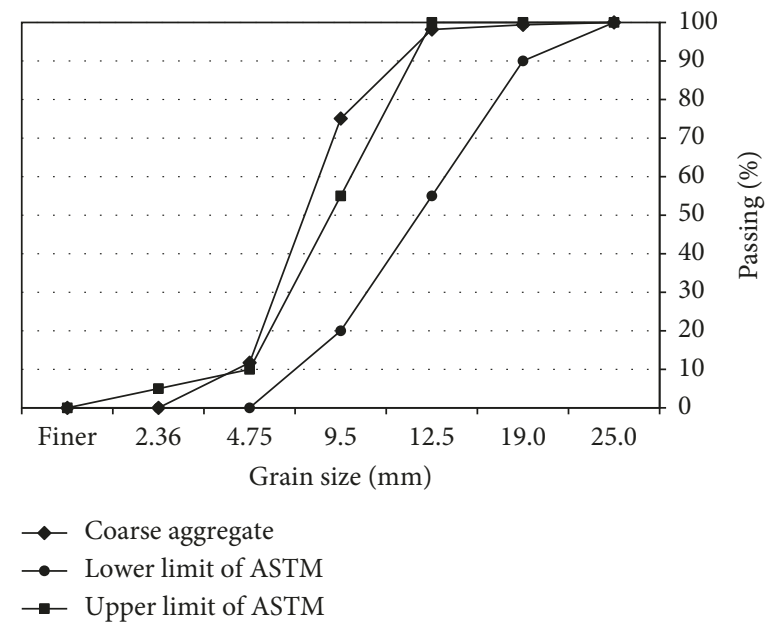

FIGURE 1: Grading curve of coarse aggregates.

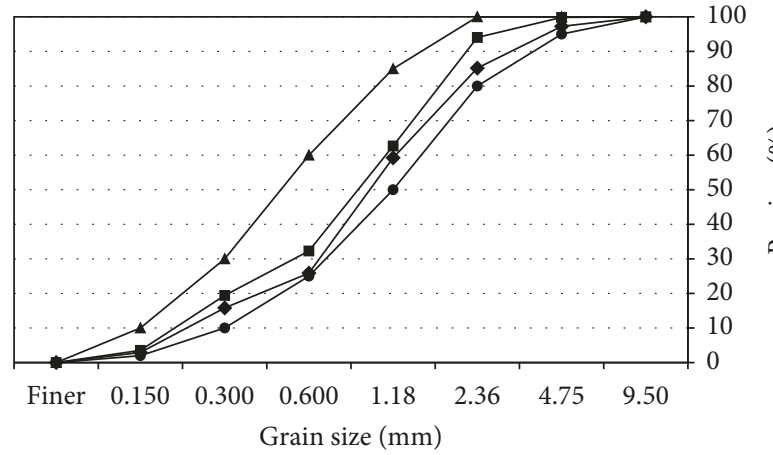

$\begin{array}{ll}\rightarrow-\text { First fine agg. } & \rightarrow-\text { Lower limit of ASTM } \\ \rightarrow-\text { Upper limit of ASTM } & \rightarrow-\text { Second fine agg. }\end{array}$

Figure 2: Grading curve of fine aggregates.

TABLe 1: Chemical properties of cement.

\begin{tabular}{ccccccccc}
\hline \multicolumn{10}{c}{ Percent by weight (\%) } \\
$\mathrm{C}_{3} \mathrm{~A}$ & $\mathrm{C}_{2} \mathrm{~S}$ & $\mathrm{C}_{3} \mathrm{~S}$ & $\mathrm{SO}_{3}$ & $\mathrm{CaO}$ & $\mathrm{MgO}$ & $\mathrm{Fe}_{2} \mathrm{O}_{3}$ & $\mathrm{Al}_{2} \mathrm{O}_{3}$ & $\mathrm{SiO}_{2}$ \\
\hline 6.50 & 24.70 & 49.70 & 1.87 & 62.61 & 3.76 & 3.19 & 4.51 & 21.70 \\
\hline
\end{tabular}

Figures 1 and 2 present grading curves of coarse and fine aggregates (sand), respectively, and Table 1 shows the result of the chemical analysis of cement.

To achieve SCC mixtures with high flow and passing abilities and at the same time avoiding segregation and bleeding in the molds, a poly carboxylic High Range Water Reducing Admixture (HRWR) and Viscosity Modifying Admixture (VMA) as chemical admixtures were used. HRWR increases the slump of concrete without increasing water content [18], and VMA can increase the cohesion and adhesion of concrete. Table 2 summarizes the properties of mix designs.

2.2. Test Procedure. The Slump Flow, J-Ring, V-Funnel, and L-Box tests [19] were used to determine the filling and passing ability of self-compacting concrete immediately after
TABLE 2: Mixture proportions.

\begin{tabular}{lccccccc}
\hline ID & G & S1 & $\begin{array}{c}\text { S2 } \\
\left(\mathrm{kg} / \mathrm{m}^{3}\right)\end{array}$ & C & W & \multicolumn{2}{c}{$\begin{array}{c}\text { V } \\
\left(\mathrm{L} / \mathrm{m}^{3}\right)\end{array}$} \\
\hline 1 & 674 & 674 & 337 & 403 & 161 & 2.5 & 3.6 \\
2 & 648 & 648 & 324 & 435 & 174 & 2.6 & 3.9 \\
3 & 622 & 622 & 311 & 467 & 187 & 2.6 & 4.2 \\
4 & 595 & 595 & 297 & 500 & 200 & 2.8 & 4.5 \\
5 & 655 & 655 & 327 & 403 & 181 & 1.8 & 3.8 \\
6 & 635 & 635 & 318 & 403 & 201 & 1.1 & 4.0 \\
7 & 694 & 694 & 347 & 403 & 141 & 3.2 & 3.4 \\
8 & 802 & 642 & 160 & 450 & 180 & 2.3 & 3.6 \\
9 & 734 & 653 & 245 & 434 & 174 & 2.7 & 4.0 \\
10 & 488 & 732 & 407 & 433 & 173 & 2.7 & 4.0 \\
11 & 724 & 644 & 242 & 456 & 183 & 2.7 & 4.0 \\
12 & 481 & 722 & 401 & 456 & 183 & 2.7 & 4.0 \\
13 & 642 & 642 & 321 & 457 & 183 & 2.7 & 4.0 \\
\hline
\end{tabular}

Note: $\mathrm{G}=$ gravel; $\mathrm{S} 1=$ Sand Type I; $\mathrm{S} 2=$ Sand Type II; C= cement weight; $\mathrm{W}=$ free water content; $\mathrm{H}=$ volume of HRWRA; $\mathrm{V}=$ volume of VMA; water-to-cement ratio $(\mathrm{w} / \mathrm{cm})=0.4$.

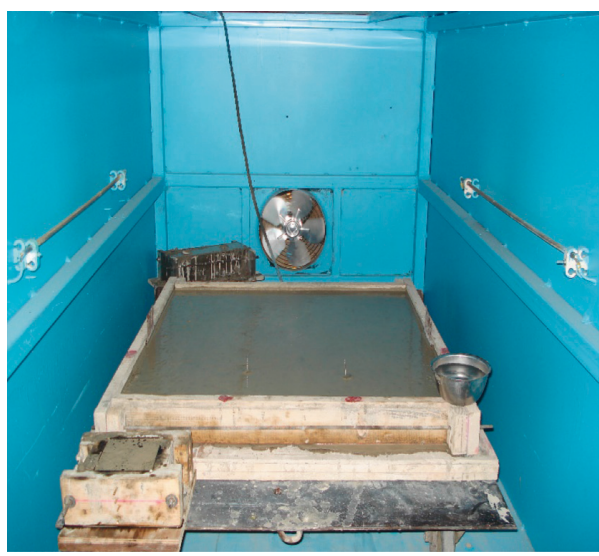

FIgURE 3: Test setup.

mixing. The specimens, which were placed in a specific slab formwork, were subjected to a wind tunnel that simulates the hot dry environmental condition of $37 \pm 2^{\circ} \mathrm{C}$ 


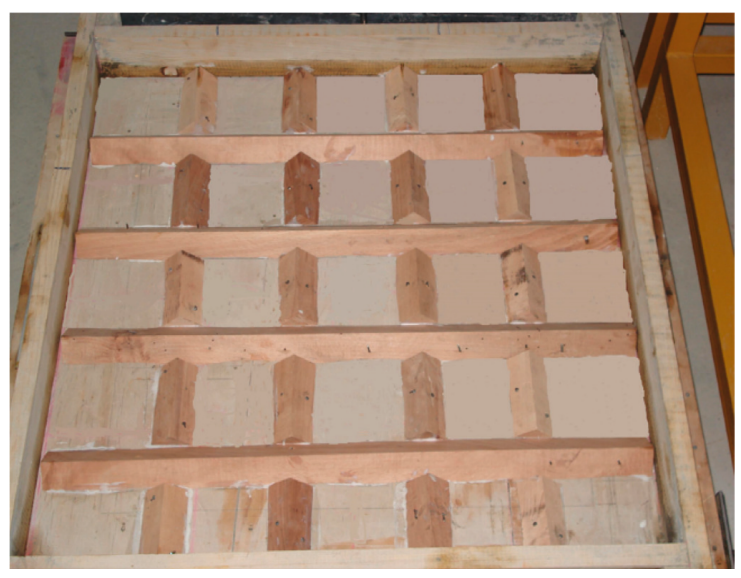

(a)

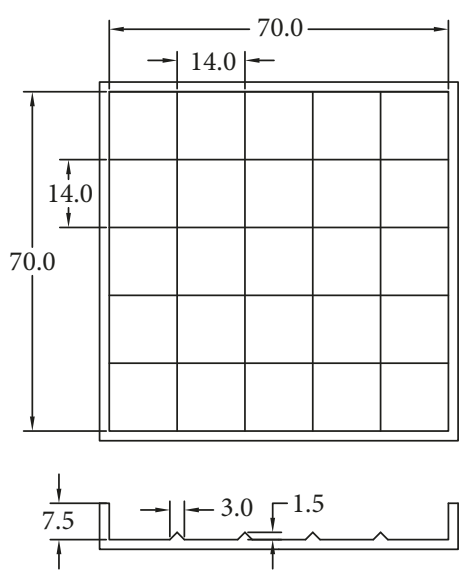

(b)

FIGURE 4: Formwork of restraint plastic shrinkage.

temperature, $43 \pm 7 \%$ relative humidity, and $1.6 \pm 0.3 \mathrm{~m} / \mathrm{s}$ wind velocity to evaluate the constraint plastic shrinkage, as illustrated in Figure 3. The evaporation rate from the surface of the concrete was determined by measuring the weight of a $100 \times 100 \times 75 \mathrm{~mm}$ cubic mold at the same time intervals with a high-precision $( \pm 0.1 \mathrm{~g})$ balance, as shown in Figure 3 . This mold was located within the wind tunnel and was positioned in the same environment as the concrete molds. Moreover, bleeding was obtained using the ASTM C232 [20]. In this way, the amount of bleeding was calculated by measuring the changes of concrete height in standard specimen specified in ASTM C232.

In the initial tests using ASTM C1579 [21] specimen, only longitudinal cracks were observed due to the relative high height of central restraint and different mixture designs had negligible effect on the test results. Therefore, for getting better results, some modifications were made on the standard specimen mentioned in ASTM C1579, by providing two perpendicular constraints with equal height and increasing the height of mid restraint. These modifications cause concrete to crack on the weakest section due to plastic settlement. The formwork of restrained plastic shrinkage was fabricated from wood, with triangular woody prisms installed in the bottom to restrain fresh concrete as illustrated in Figure 4.

Since contraction strain measurement for fresh concrete is an arduous process, and advanced devices like Vibrating Wire Strain Gauges [22, 23] (VWSG) were not available during this project due to their high costs, a new innovative method was utilized for the strain measurement. In this method, a laser generator, two indicators located on the fresh concrete, and one mounting support (Figure 5) were developed to project the short distance between two indicators to a more significant measurable length on a wall $(L)$ every 15 minutes until the first crack was observed as shown in Figure 6.

The tensile strain of the concrete can be calculated by using the following equation:

$$
\Delta C=\frac{1-L^{\prime}}{L},
$$

where $L=$ initial distance between two images of indicators and $L^{\prime}=$ distance between two images of indicators before finding the first crack.

The tensile strain of free concrete $(\Delta F)$ was measured simultaneously with the same process by a $75 \mathrm{~mm}$ cube glass mold in which all the internal surfaces were covered with grease, as illustrated in Figure 7.

Finally, the tensile strain capacity $(T)$ is calculated by the following equation:

$$
T=\Delta F-\Delta C \text {. }
$$

\section{Test Results and Discussion}

Two samples were used for each mixture, and the average results of fresh and hardened concrete are presented in Table 3. By comparing the result of mixtures No. 1 to 4 , it is concluded that increasing the cement paste volume can increase the total cracking area and the maximum crack width. Moreover, results of mixtures No. 11 to 13 show that increasing the coarse to total aggregate ratio will decrease the total cracking area and the maximum crack width.

As identified by some researchers, when the total evaporation and total bleeding rates are equal, pore water pressure begins to decrease. Therefore, the difference between bleeding and evaporation was selected as the independent variable plotted against free plastic strains to investigate their relationship. The results of 4 out of 13 tests are shown in Figure 8. The results show that the relationship of the difference between bleeding and evaporation and free plastic shrinkage strain (by passing the time) is linear. The slope of this line for each mixture depends on the mixture specification.

Plastic shrinkage cracking depends on the amount of free plastic shrinkage strain, restraining factor, and the tensile strain capacity of concrete. As previously noted, the restraining factor can be calculated by equations (1) and (2). The restraining factor is a substantial property of formwork, and it is equal to $82 \%$ for this study. Equation (5) is suggested based on the best curve fitting the test results to predict the tensile strain capacity of self-compacting concrete: 


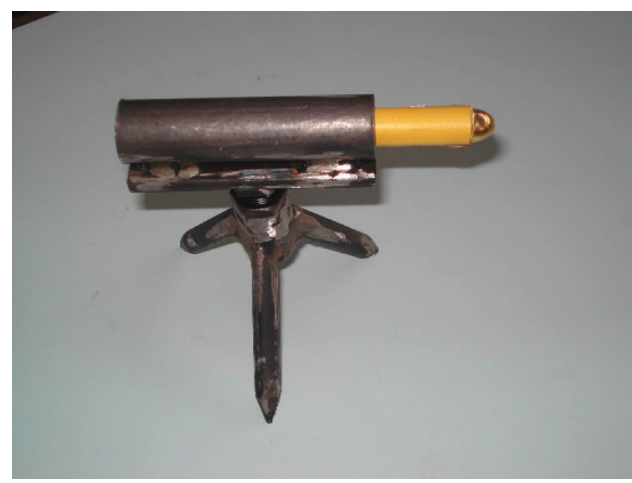

(a)

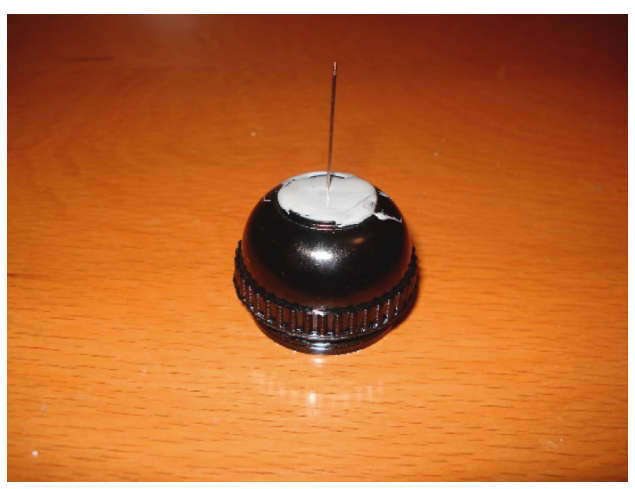

(b)

Figure 5: Tensile strain measuring equipment. (a) Rotary laser generator. (b) Indicator.

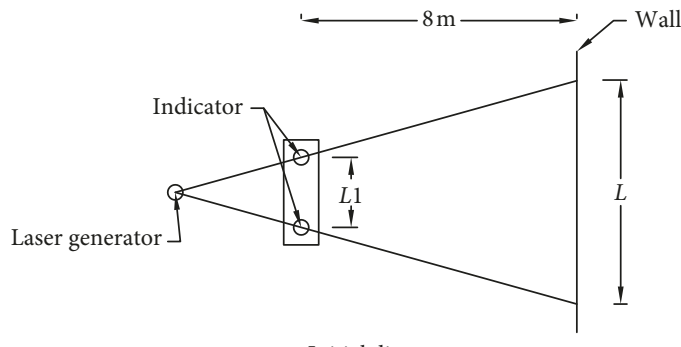

Initial distance

(a)

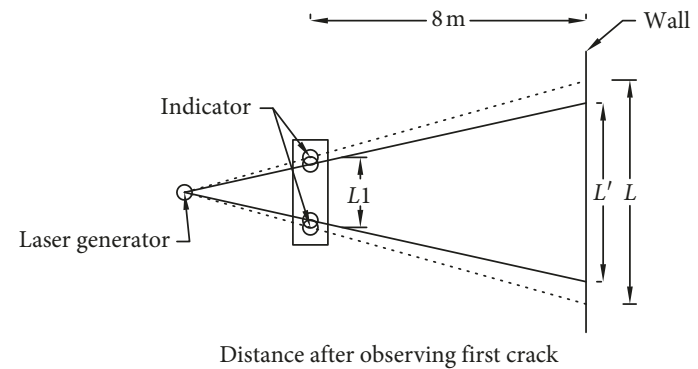

(b)

FIgURE 6: Tensile strain measurement. (a) Initial distance. (b) Distance after observing first crack.

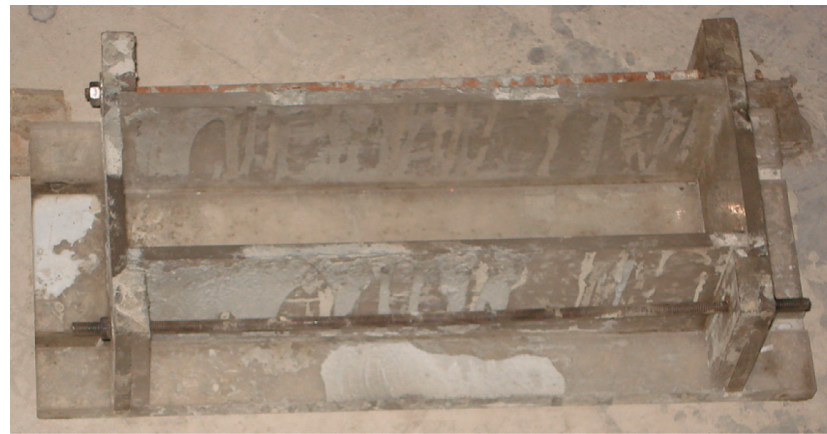

Figure 7: The glass mold for measuring free tensile strain.

$$
T=4090 D_{\mathrm{av}}-8730 V_{\mathrm{p}}+5320 W+1318
$$

where $T=$ tensile strain capacity (microstrain), $D_{\mathrm{av}}=$ average diameter of total aggregate $(\mathrm{cm}), V_{\mathrm{p}}=$ paste volume $\left(\mathrm{m}^{3} / \mathrm{m}^{3}\right)$, and $W=$ water-to-cement ratio.

Plastic shrinkage cracking area is calculated by the following equation:

$$
\mathrm{PC}=\frac{K_{1} R K_{2}(E-B)}{T},
$$

where $\mathrm{PC}=$ plastic shrinkage cracking area in unit surface of concrete $\left(\mathrm{cm}^{2} / \mathrm{m}^{2}\right), R=$ restraining factor $(\%), E=$ total evaporation from unit surface of concrete $(\mathrm{g}), B=$ total bleeding from unit surface of concrete $(\mathrm{g}), T=$ tensile strain capacity (microstrain), $K_{1}=7.53$ (rational factor) $\left(\mathrm{g}^{-1}\right)$, and $K_{2}=4.48$ (average slope of free plastic shrinkage versus the difference between bleeding and evaporation)

In equation (6), $K_{2}$ depends on concrete characteristics; however, for simplifying the proposed equation, this parameter is assumed equal to the average of all the mixtures. Also, $K_{1}$ is calculated based on the best curve fitting the test results. By replacing the amount of $K_{1}, K_{2}$, and SC in equation (6), equation (7) is achieved. The proposed equation in this study is obtained based on the test results of 13 SCC mixtures. The predicted plastic shrinkage versus actual test results is plotted in Figure 9 to indicate the amount of error. The points located in line with 45 degrees shows that the error is zero, and proposed results are equal to the actual test results. 
TABLE 3: Test results.

\begin{tabular}{|c|c|c|c|c|c|c|c|c|c|c|c|}
\hline Mix & $f_{\mathrm{c} 28 \mathrm{~d}}$ & $V_{\mathrm{p}}$ & $\begin{array}{l}\text { Max. crack } \\
\text { width }\end{array}$ & PC & $\begin{array}{l}\text { Tensile strain } \\
\text { capacity }\end{array}$ & $D_{\mathrm{av}}$ & $\begin{array}{c}\text { Coarse/ } \\
\text { aggregate }\end{array}$ & $\begin{array}{l}\text { Slump } \\
\text { flow }\end{array}$ & $\begin{array}{l}\mathrm{J}- \\
\text { ring }\end{array}$ & $\begin{array}{c}\text { V-funnel, } \\
\text { V\&M }\end{array}$ & $\begin{array}{c}\text { L- } \\
\text { box }\end{array}$ \\
\hline no. & $\mathrm{MPa}$ & $\begin{array}{l}\mathrm{L} / \\
\mathrm{m}^{3}\end{array}$ & $\mathrm{~mm}$ & $\begin{array}{l}\mathrm{cm}^{2} / \\
\mathrm{m}^{2}\end{array}$ & $\mathrm{~mm} / \mathrm{mm}$ & $\mathrm{mm}$ & Ratio & $\mathrm{mm}$ & $\mathrm{mm}$ & $\mathrm{sec}$ & Ratio \\
\hline 1 & 58 & 329 & 0.2 & 1.9 & 2229 & 39 & 0.4 & 670 & 20 & 20 & 0.70 \\
\hline 2 & 49 & 355 & 0.4 & 26.6 & 1974 & 39 & 0.4 & 700 & 10 & 7 & 0.75 \\
\hline 3 & 44 & 381 & 0.5 & 38 & 1654 & 39 & 0.4 & 740 & 10 & 4 & 0.80 \\
\hline 4 & 41 & 408 & 0.55 & 54.3 & 1568 & 39 & 0.4 & 760 & 5 & 4 & 0.85 \\
\hline 5 & 40 & 349 & 0.2 & 0.7 & 2283 & 39 & 0.4 & 720 & 5 & 4 & 0.80 \\
\hline 6 & 34 & 368 & 0 & 0 & 2506 & 39 & 0.4 & 750 & 0 & 3 & 0.85 \\
\hline 7 & 43 & 310 & 0.2 & 7.8 & 2053 & 39 & 0.4 & 730 & 10 & 3 & 0.80 \\
\hline 8 & 50 & 363 & 0.35 & 30.9 & 1897 & 46 & 0.5 & 780 & 20 & 12 & 0.82 \\
\hline 9 & 43 & 351 & 0.45 & 18 & 2097 & 43 & 0.45 & 670 & 20 & 15 & 0.68 \\
\hline 10 & 37 & 350 & 0 & 0 & 2473 & 33 & 0.3 & 655 & 30 & 52 & 0.73 \\
\hline 11 & 45 & 359 & 0.35 & 33.4 & 1659 & 43 & 0.45 & 755 & 10 & 3 & 0.80 \\
\hline 12 & 37 & 360 & 0.45 & 39.2 & 1329 & 33 & 0.3 & 675 & 10 & 5 & 0.72 \\
\hline 13 & 40 & 361 & 0.4 & 35.3 & 1582 & 39 & 0.4 & 730 & 10 & 4 & 0.78 \\
\hline
\end{tabular}

Note: $\mathrm{PC}=$ plastic shrinkage cracking area in the unit surface of concrete; $D_{\mathrm{av}}=$ average diameter of total aggregate.

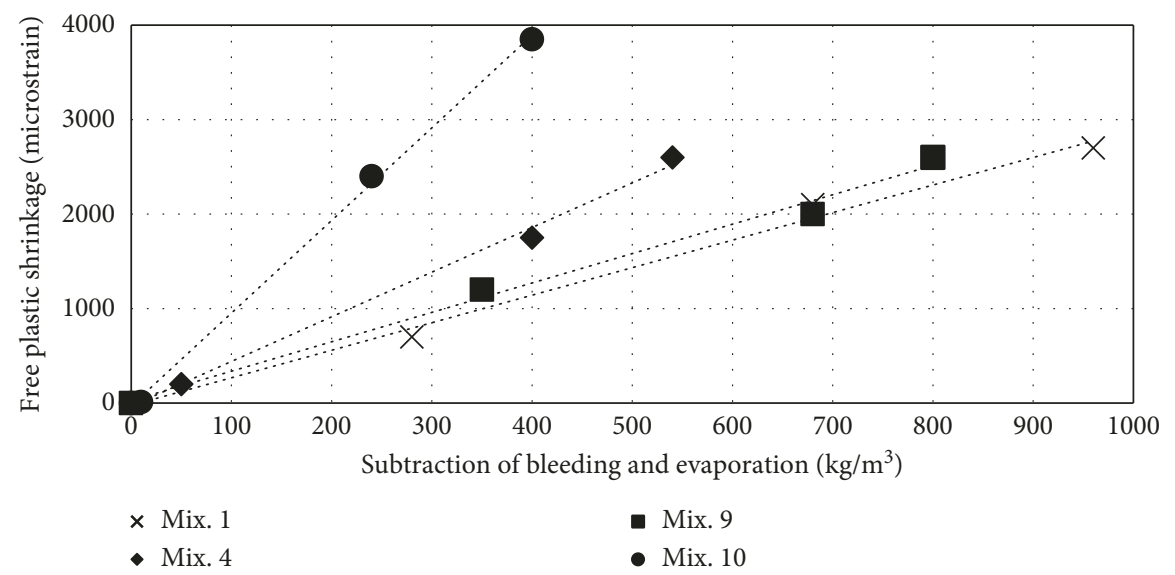

FIgURE 8: Free plastic shrinkage versus the difference between bleeding and evaporation.

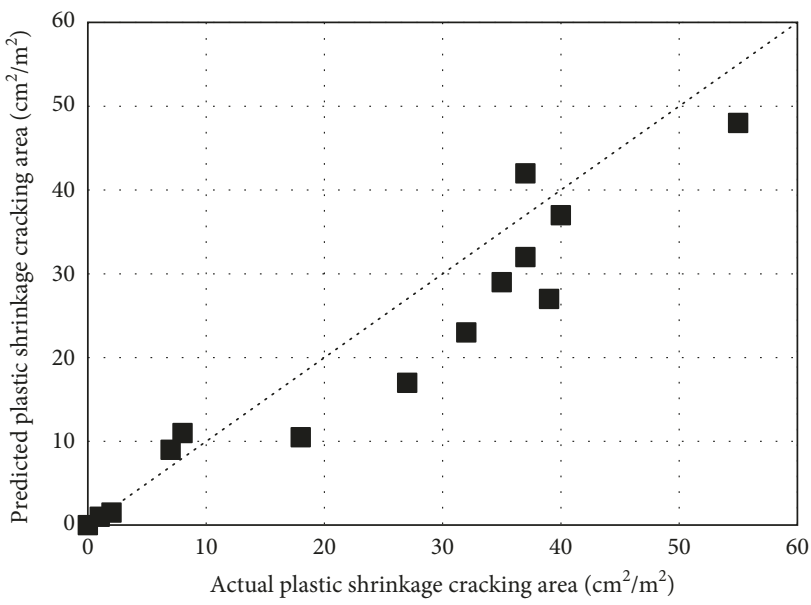

Figure 9: Actual plastic shrinkage cracking area versus the predicted area.

Equation (7) shows that the average diameter of total aggregates, water-to-cement ratio, cement paste volume, evaporation rates, bleeding, and the restraining factor are the effective parameters in plastic shrinkage cracking area of concrete:

$$
\mathrm{PC}=\frac{33.73 R(E-B)}{\left(100\left(4090 D_{\mathrm{av}}-8730 V_{\mathrm{p}}+5320 W+1318\right)\right)} .
$$

\section{Conclusion}

Plastic shrinkage of 13 self-compacting concrete samples exposed to hot climatic conditions with different water/ cement ratios, cement paste volumes, and course aggregate/ total aggregate ratios was studied. The test results show that free plastic shrinkage strain depends on time and has a linear relationship with the difference between bleeding and evaporation. The slope of this linear relationship in each mixture is associated with concrete characteristics.

It can also be observed from the test results that the increase in time and amount of bleeding, the average diameter of total aggregates, water/cement ratio, and the decrease in the cement paste volume, concrete surface evaporation rate, and the restraining factor are major parameters that can decrease the plastic shrinkage cracking 
area of concrete. Based on the results of 13 SCC mixtures, a new equation is presented to predict the plastic shrinkage cracking area of self-compacting concrete. The proposed model can be used as an initial estimation for plastic shrinkage of SCC mixtures. However, more in-depth studies considering other related variables to plastic shrinkage are needed for modification of the model in the future works.

\section{Data Availability}

The authors confirm that the data supporting the findings of this study are included within the article.

\section{Conflicts of Interest}

The authors declare that they have no conflicts of interest.

\section{References}

[1] D. Garber and E. Shahrokhinasab, Performance Comparison of In-Service, Full-Depth Precast Concrete Deck Panels to CastIn-Place Decks, Florida International University, University Park, FL, USA, 2018.

[2] A. M. Abbasi, E. Shahrokhinasab, and J. A. Zakeri, "Field studies on the effects of under sleeper pads in lateral resistance of railway," Journal of Structural and Construction Engineering, vol. 3, no. 1, pp. 14-26, 2016.

[3] P. Turcry and A. Loukili, "Evaluation of plastic shrinkage of self compacting concrete," ACI Materials Journal, vol. 103, pp. 272-279, 2006.

[4] C. Qi, J. Weiss, and J. Olek, "Characterization of plastic shrinkage cracking in fiber reinforced concrete using image analysis and a modified Weibull function," Materials and Structures, vol. 36, no. 6, pp. 386-395, 2003.

[5] K. Wang, S. P. Shah, and P. Phuaksuk, "Plastic shrinkage cracking in concrete materials-influence of fly ash and fibers," ACI Materials Journal, vol. 98, no. 6, pp. 458-464, 2001.

[6] E. Erten, Ç. Yalçınkaya, A. Beglarigale, H. Yiğiter, and H. Yazıc1, "Erken yaş büzülme çatlaklarının lif içeren/içermeyen ultra yüksek performanslı betona gömülü donatı korozyonuna etkisi," Gazi Üniversitesi Mühendislik-Mimarlık Fakültesi Dergisi, vol. 32, no. 4, pp. 1347-1364, 2017.

[7] R. Abbasnia, P. Godossi, and J. Ahmadi, "Prediction of restrained shrinkage based on restraint factors in patching repair mortar," Cement and Concrete Research, vol. 35, no. 10, pp. 1909-1913, 2005.

[8] C. K. Leung, A. Y. Lee, and R. Lai, "New testing procedure for shrinkage cracking of fiber-reinforced shotcrete," Journal of Materials in Civil Engineering, vol. 19, no. 3, pp. 214-218, 2007.

[9] A. Leemann, P. Nygaard, and P. Lura, "Impact of admixtures on the plastic shrinkage cracking of self-compacting concrete," Cement and Concrete Composites, vol. 46, pp. 1-7, 2014.

[10] W. P. Boshoff and R. Combrinck, "Modelling the severity of plastic shrinkage cracking in concrete," Cement and Concrete Research, vol. 48, pp. 34-39, 2013.

[11] H. B. Poorsaheli, A. Behravan, S. T. T. Aghda, and A. Gholami, "A study on the durability parameters of concrete structures reinforced with synthetic fibers in high chloride concentrated shorelines," Construction and Building Materials, vol. 200, pp. 578-585, 2019.

[12] K. Behfarnia and A. Behravan, "Application of high performance polypropylene fibers in concrete lining of water tunnels," Materials \& Design, vol. 55, pp. 274-279, 2014.
[13] Y. Li and J. Li, "Capillary tension theory for prediction of early autogenous shrinkage of self-consolidating concrete," Construction and Building Materials, vol. 53, pp. 511-516, 2014.

[14] S. Altoubat, M. Talha Junaid, M. Leblouba, and D. Badran, "Effectiveness of fly ash on the restrained shrinkage cracking resistance of self-compacting concrete," Cement and Concrete Composites, vol. 79, pp. 9-20, 2017.

[15] A. Valikhani, A. J. Jahromi, and A. Azizinamini, Retrofitting Damaged Bridge Elements Using Thin Ultra High Performance Shell Elements, No. 17-02047, 2017.

[16] A. Valikhani, A. J. Jahromi, and A. Azizinamini, Experimental Investigation of High-Performing Protective Shell Used for Retrofitting Bridge Elements, No. 18-05142, 2018.

[17] ACI Committee 304, "Placing concrete by pumping methods (ACI 304.2R-96)," in ACI Manual of Concrete Practice, American Concrete Institute, Farmington Hills, MI, USA, 2013.

[18] A. A. Ramezanianpour, A. Zolfagharnasab, F. B. Zadeh et al., "Effect of supplementary cementing materials on concrete resistance against sulfuric acid attack," in High Tech Concrete: Where Technology and Engineering Meet, pp. 2290-2298, Springer, Cham, Switzerland, 2018.

[19] M. Lanier, C. Badman, J. Bareño et al., "Interim guidelines for the use of self-consolidating concrete in PCI member plants," PCI Journal, vol. 48, no. 3, pp. 14-18, 2003.

[20] ASTM C232, "Standard test methods for bleeding of pigments," Annual Book of ASTM Standard, vol. 2, pp. 2012-2013, ASTM International, West Conshohocken, PA, USA, 2013.

[21] ASTM C1579, "Standard test method for evaluating plastic shrinkage cracking of restrained fiber reinforced concrete," Annual Book of ASTM Standard, ASTM International, West Conshohocken, PA, USA, 2006.

[22] M. Abedin and A. B. Mehrabi, "Novel approaches for fracture detection in steel girder bridges," Infrastructures, vol. 4, no. 3, p. 42, 2019.

[23] M. Abedin, S. Farhangdoust, and A. B. Mehrabi, "Fracture detection in steel girder bridges using self-powered wireless sensors," in Proceedings of the Risk-Based Bridge Engineering: 10th New York City Bridge Conference, p. 216, CRC Press, New York City, NY, USA, August, 2019. 


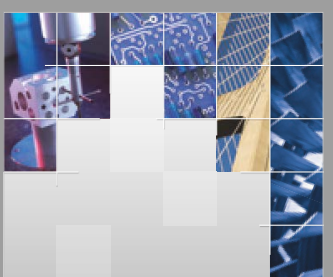

\section{Enfincering}
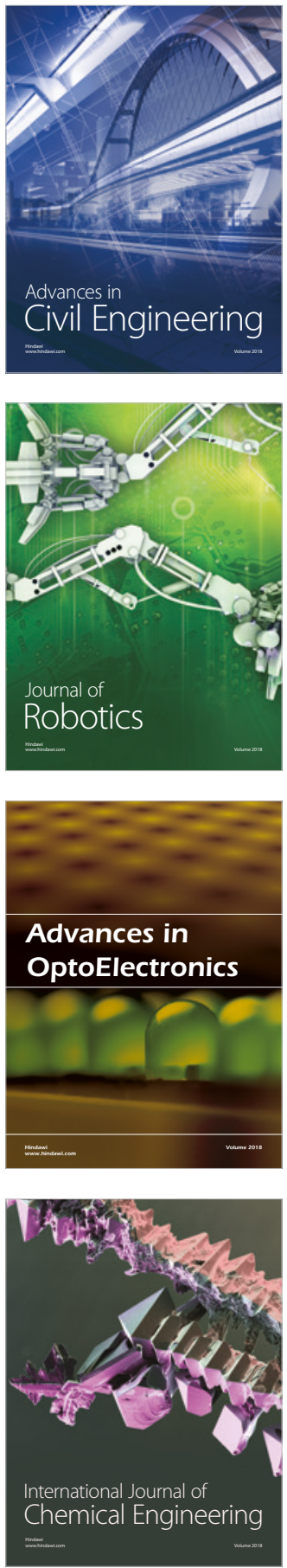

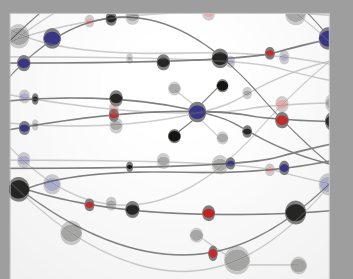

\section{Rotating \\ Machinery}

The Scientific World Journal

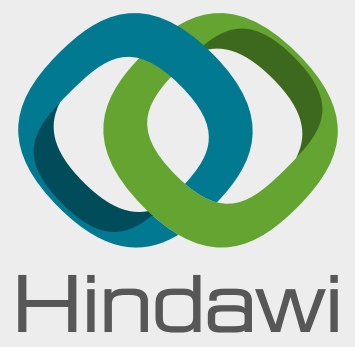

Submit your manuscripts at

www.hindawi.com
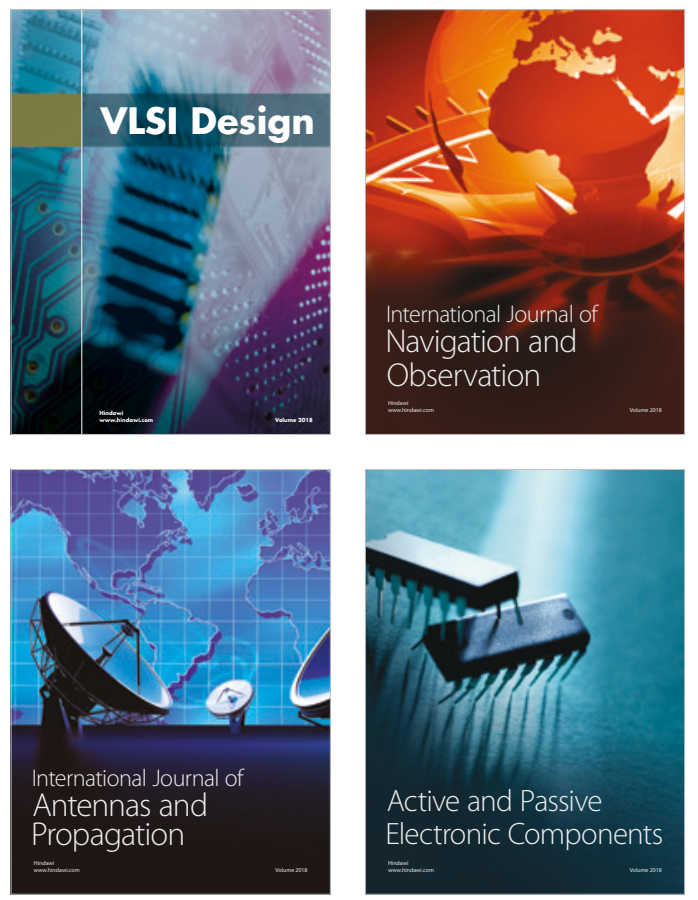
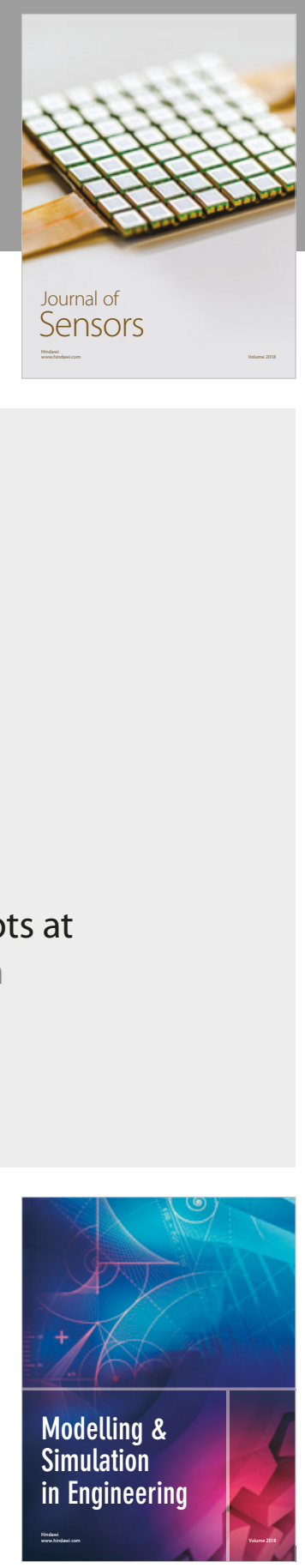

\section{Advances \\ Multimedia}
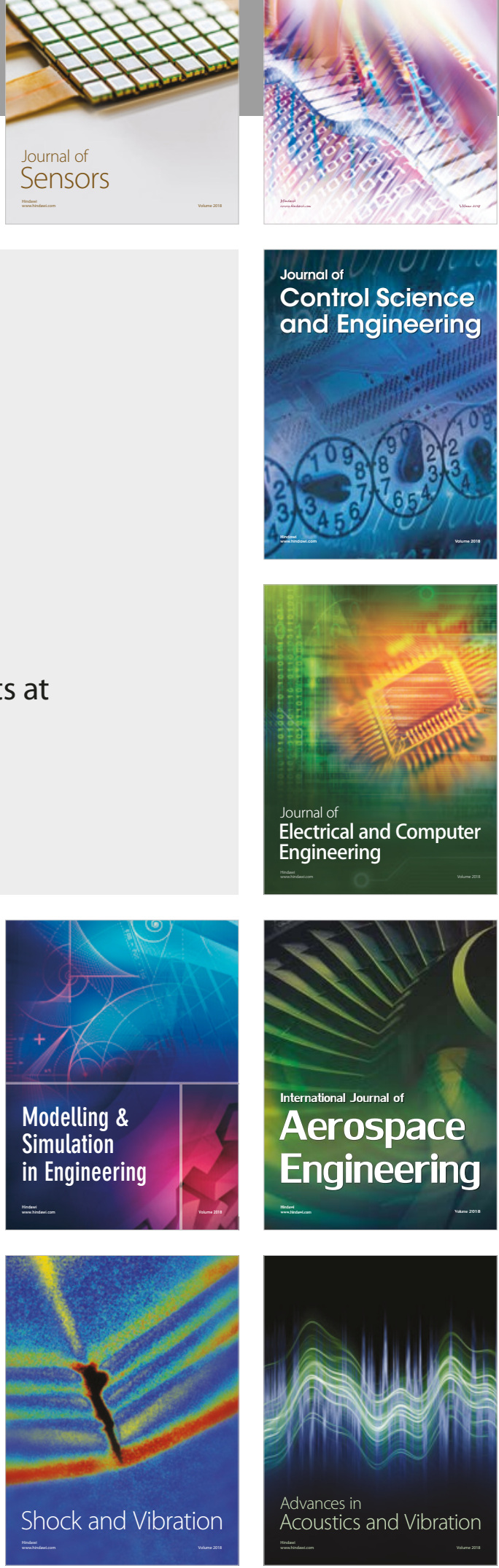